\title{
Immigrant Education and Race: Alternative Approaches to "Americanization" in Los Angeles, 1910-1940
}

\section{Zevi Gutfreund}

This article explores citizenship's multiple meanings in Los Angeles by describing five different types of Americanization, or immigrant education, in the city of angels from 1910 to 1940. The federal racialization of access to citizenship influenced these alternative approaches to Americanization at a local level. In the context of Supreme Court rulings and federal laws that made it difficult for immigrants of color to naturalize in the United States during the Progressive Era, Anglo officials in the school district and settlement houses developed an English-only curriculum that benefited only European immigrants. In response to such restrictions, Mexican and Fapanese educators in turn developed programs that showed how learning Spanish and Fapanese made their children loyal Americans worthy of citizenship. In the decades before internment and the Zoot Suit Riots, language instruction was one of the few vehicles that allowed Mexican and Fapanese Angelinos the opportunity to take control of their Americanization experiences despite the racialized constraints they faced.

In the spring of 1926, two Los Angeles city schools selected ethnic minorities to deliver commencement addresses. The speeches pushed each student to grapple with their identities as Americans. The Twenty-Eighth Street School represented the typical story associated with the Progressive Era: It celebrated the graduation of seven foreign women from an Americanization class, inviting dignitaries such as the State Superintendent of Public Instruction and the former Presidente Generale of Mazatlan, Mexico. ${ }^{1}$ In a class of sixty-seven immigrants,

Zevi Gutfreund is Assistant Professor of History at Louisiana State University and advisor of the Social Studies Secondary Education teacher certification program (Geaux Teach!). This article is based, in part, on research completed for the first two chapters of the author's forthcoming manuscript, currently titled Active Voices: Language Education and the Remaking of American Citizenship in Los Angeles, 1900-1998.

\footnotetext{
${ }^{1}$ Mary Gibson, "Schools for the Whole Family," The Survey 56, no. 5 (June 1, 1926), 300.
} 
only seven were graduating. Mrs. Portillo, one of the graduates and the Mazatlan official's sister-in-law, articulated her classmates' struggles and aspirations:

You don't realize how sad I was because I couldn't understand any word in English. I thought I was the most ignorant person in the world. I am in the middle way of my ambitions and I shall try to climb until I reach the top. My aim is to be a Spanish teacher in the schools here. Today is the happiest day of my life. ${ }^{2}$

Mrs. Portillo's goals reflected the agendas of both her Progressive Era teachers and LA's Mexican community. She wanted to speak English and advance professionally, but she also wanted to teach Spanish. Unlike later culture wars, when lines were drawn between Englishonly advocates and those who wanted to teach immigrants in their mother tongue, Mrs. Portillo believed in both types of language instruction. In contrast to future debates about "bilingual education," this privileged mother with ties to Mexican officials suggested that international diplomacy made the politics of language learning seem less polarizing in the Progressive Era.

Graduating senior John Aiso encountered more discrimination at Hollywood High School that June when he became the school's first Japanese American salutatorian. This was one of many bittersweet honors for the seventeen-year-old Nisei (second-generation Japanese students born in America). Three years earlier, when Aiso was elected student body president of his middle school in a neighborhood with outspoken opponents of Japanese immigration, Anglo parents complained so loudly that the principal urged him to leave student government. But the middle school election was less complex than Hollywood High's oratorical contest on the US Constitution, which Aiso won as a junior and a senior. After his 1926 salutatorian victory, the Los Angeles Times reported that the "Japanese silver tongue" would not compete in the national contest in Washington, DC, due to illness. ${ }^{3}$ The Times later added that although Aiso had withdrawn, his performances had "inspired his fellow students at Hollywood" to pay the expense of his Washington trip so he could coach the school's runner-up, Herbert Wenig. Unfazed, Aiso arrived at the train station in a bow tie and fedora and smiled as he stood behind Wenig, who was six inches taller but

\footnotetext{
${ }^{2}$ Gertrude Ford, "A Home Teacher Graduation," Community Exchange Bulletin 4, no. 4 (May 1926), 19. Ford refers to all seven graduates by their last names only: Mrs. Portillo, Mrs. Barrera, Mrs. Cohen, Mrs. Kirschenbaum, Mrs. Boehme, Mrs. Herdoch, and Mrs. Feintech.

3 "Boy Orator On Way East," Los Angeles Times, May 30, 1926, 4.
} 
dressed the same. ${ }^{4}$ Aiso watched Wenig win the national championship on Capitol Hill in front of eight thousand spectators, including President Coolidge. As the new national president of the Constitution Club, Wenig was invited to speak to the Daughters of the American Revolution and the Better America Federation back in Los Angeles. But the Hollywood High senior class still wanted John Aiso to give their graduation address. ${ }^{5}$

John Aiso and Mrs. Portillo did not represent the average Mexican immigrant or Japanese American students, but their transnational ties influenced the range of opportunities available to immigrants in Los Angeles during the age of Americanization. The city schools offered pathways to civic participation to adult immigrants like Portillo, a mother of five who had gone to college in Mexico before the 1910 revolution, as well as to American-born teenagers like Aiso and other Nisei students. Work ethic and intelligence did not stop their struggles in school, although Portillo's language barrier was different from the discrimination that denied Aiso his titles as student body president and oratorical champion. While they both used school success to propel their future careers in America, they never abandoned their mother tongues. In the fall of 1926, Portillo became a Spanish teacher and Aiso spent a year in Japan, where he continued the language study he had begun in Los Angeles. Writing from Tokyo a year later, Aiso insisted that he was witnessing "the dawn of a new Pacific era." ways in which issues of race, language, and citizenship status shaped the experience of Americanization in the years before World War II. Debates over language instruction show how teachers, students, and parents argued about the role LA's immigrant families would play in Aiso's "new Pacific era."

This is not the first work to examine multiple ethnic groups in Los Angeles schools. Previous scholars have celebrated the city's rich diversity by focusing on either teachers or students. In their accounts of working-class neighborhoods, like Boyle Heights in East LA, Allison Varzally and Mark Wild both argue that adolescent Angelinos created new cultural identities simply by interacting with neighbors and classmates of other races. ${ }^{7}$ At Roosevelt High School in Boyle Heights,

\footnotetext{
4 “Oratory Champion Arrives Home," Los Angeles Times, June 16, 1926, A1.

5 "John Aiso to Visit Japan," Los Angeles Times, Oct. 28, 1926, A11.

"John Aiso to Visit Japan"; John F. Aiso, "As Japan Sees America," Los Angeles Times, July 31, 1927, B4.

${ }^{7}$ Mark Wild, Street Meeting: Multiethnic Neighborhoods in Early Twentieth-Century Los Angeles (Berkeley: University of California Press, 2005); Allison Varzally, Making a Non-White America: Californians Coloring Outside Ethnic Lines, 1925-1955 (Berkeley: University of California Press, 2008).
} 
students organized "international dress-up days" to honor their parents' diverse traditions, helping Angelinos overcome ethnic differences and forging lasting personal and political bonds. Meanwhile, other historians have examined how LA educators designed their curriculum to accommodate the region's unique student population. In her biography of Helen Heffernan and Corinne Seeds, Kathleen Weiler tells the story of two administrators who shaped education policy and practice for urban and migrant children in Southern California from the Progressive Era to the Cold War. ${ }^{8}$ Heffernan, in particular, supervised instruction of Spanish-speaking children during World War II before Douglas MacArthur invited her to Tokyo to revamp the Japanese school system during the American occupation. She continued the tradition of Progressive Era educators rewriting California's curriculum, as described by Judith Raftery, whose extensive account of the Home Teacher Act of 1915 shows how women used LA's growing immigrant population to create the school district's first positions for female administrators. ${ }^{9}$ This article returns to the Home Teacher Act, and other innovations in immigrant education, to understand how ambitious educators and assimilated students worked together to create new meanings of citizenship and Americanization in Los Angeles. ${ }^{10}$

Americanization and citizenship education dominated the national conversation about public schools in the years between the two world wars. Mass immigration in the decades before the National Origins Act of 1924 brought an abundance of foreign languages to the United States, along with a burning desire to learn English and assimilate. But applying the Progressive Era label of Americanization inaccurately assumes that all immigrants easily adapted into a mythical melting pot. Although many ethnic groups did attribute their social integration to acquiring proficiency in English, some nonwhite immigrants grew ambivalent about English as they struggled to assimilate. In Los Angeles, sociologists and social reformers believed the lack of language learning among two of the city's largest racial minority groups was central to the "Mexican Problem" and the "Oriental Problem." Many Mexican and Japanese immigrants agreed with the basic premise of white progressives, though they had their own views about language

\footnotetext{
${ }^{8}$ Kathleen Weiler, Democracy and Schooling in California: The Legacy of Helen Heffernan and Corinne Seeds (New York: Palgrave Macmillan, 2011).

${ }^{9}$ Judith Rosenberg Raftery, Land of Fair Promise: Politics and Reform in Los Angeles Schools, 1885-1941 (Stanford, CA: Stanford University Press, 1992).

${ }^{10}$ For the larger context of education policies toward ethnically diverse students beyond Los Angeles, see Ruben Flores, Backroads Pragmatists: Mexico's Melting Pot and Civil Rights in the United States (Philadelphia: University of Pennsylvania Press, 2014) and Carlos Kevin Blanton, George I. Sánchez: The Long Fight for Mexican American Integration (New Haven, CT: Yale University Press, 2014).
} 
and citizenship. From 1903 to 1930, Mexicans, Japanese, and Anglos used school district publications and student oratorical contests to propose new ideas about immigrant education to the state legislature. These innovative Americanization proposals showed that transnational networks used language curricula to counter the English-only efforts of nativist agitators.

Although Angelinos were active in these Americanization debates, they have largely been forgotten since the Progressive Era. Recent scholarship has challenged the assumption that Americanization was simply an effort to assimilate immigrants by eliminating children's previous ethnic cultures and replacing them with social, political, and moral attitudes acceptable to mainstream Americans. In two recent histories of education between the world wars, Diana Selig and Zoë Burkholder argue that Americanization and intercultural education became a central component of the "antiprejudice crusade" led by affluent progressive educators. ${ }^{11}$ Jeffrey Mirel adds that immigrants embraced key aspects of Americanization, including learning English, because they viewed American democracy as a protector of their cultural heritages. ${ }^{12}$ While these studies shift the focus of Americanization from forced assimilation to a cultural negotiation, their narratives are largely limited to European immigrants in the Midwest and Atlantic seaboard. Americanization curricula in the West has received attention from Frank Van Nuys and Yoon Pak, who have added the experiences of immigrants from Asia and Latin America to the narrative. ${ }^{13}$ This article builds on that scholarship by comparing how Mexican and Japanese educators in Los Angeles designed language instruction programs to complement and compete with the city's Americanization agenda. While the school district insisted on English-only classrooms, racialized groups promoted immigrant education in LA as the antidote to nativist calls for forced assimilation. ${ }^{14}$

Angelino educators celebrated a series of experiments in the schooling of foreign-born students that made Los Angeles a laboratory for questions about language and citizenship in an age of mass

${ }^{11}$ Diana Selig, Americans All: The Cultural Gifts Movement (Cambridge, MA: Harvard University Press, 2008); Zoë Burkholder, Color in the Classroom: How American Schools Taught Race, 1900-1954 (New York: Oxford University Press, 2011).

${ }^{12}$ Jeffrey Mirel, Patriotic Pluralism: Americanization Education and European Immigrants (Cambridge, MA: Harvard University Press, 2010).

${ }^{13}$ Frank Van Nuys, Americanizing the West: Race, Immigrants, and Citizenship, 18901930 (Lawrence: University Press of Kansas, 2002); Yoon Pak, Wherever I Go, I Will Always Be a Loyal American: Schooling Seattle's Fapanese Americans During World War II (New York: Routledge/Falmer, 2002).

${ }^{14}$ All these works build off John Higham's original study of Americanization as a nativist movement. John Higham, Strangers in the Land: Patterns of American Nativism, 1860-1925 (New Brunswick, NJ: Rutgers University Press, 1955). 
immigration. They believed progressives across the nation looked to LA for the latest Americanization innovations. In 1926, The Survey praised the "California Plan" for questioning the xenophobic application of "Americanization." According to this progressive magazine, Angelinos rejected reactionary politics and remade the term:

\begin{abstract}
"Americanization," a smug and patronizing word at best, means in many communities a waning war-time enthusiasm, now expressed through a few classes in English for Foreigners. But in California it has been translated into something vital. ... This far reaching innovation in the public school system is California's unique contribution to the "new education." 15
\end{abstract}

In negotiating between postwar extremism and participatory democracy, LA reformers captured the contradictions of Americanization. They developed lessons that taught immigrants to adopt middleclass Protestant values, took pride in their social reform efforts, and intended to create a liberal legacy that would shape the political culture of the "city of the future."

But white reformers represented only one voice in LA's language debate, albeit the loudest. Americanization challenged immigrants as they struggled to acquire English without losing their native dialect, but they rarely recorded their experiences unless, like Mrs. Portillo, they spoke in Anglo publications. Historians of Mexican Americans and Japanese Americans have tried to identify immigrant voices in Anglo accounts. Vicki Ruiz used oral histories of Mexican women to bypass the filter of personal prejudice. ${ }^{16}$ Henry $\mathrm{Yu}$ argued that Anglo reformers shaped not only how whites viewed Asian Americans, but also how they understood themselves. ${ }^{17}$ Looking at Anglo, Mexican, and Japanese Angelinos together reveals a range of language instruction possibilities in the age of Americanization. As disparate

15 "Education for Everybody: The California Plan," The Survey 56, no. 5 (June 1, 1926), 297. This Los Angeles plan was quite different from how earlier California progressives approached Americanization, such as Ellwood Cubberley, who in 1909 declared that the primary task of educators was "to assimilate and amalgamate these people as a part of our American race, and to implant in their children ... the Anglo-Saxon conception of righteousness, law and order, and popular government." Ellwood Patterson Cubberley, Changing Conceptions of Education (New York: Houghton Mifflin, 1909), 15.

${ }^{16}$ Vicki L. Ruíz, "Dead Ends or Gold Mines?: Using Missionary Records in Mexican American Women's History," in Unequal Sisters: A Multicultural Reader in U.S. Women's History, 2nd ed., ed. Vicki Ruiz and Ellen DuBois (New York: Routledge, 1994), 298.

${ }^{17}$ Henry Yu, Thinking Orientals: Migration, Contact, and Exoticism in Modern America (New York: Oxford University Press, 2001), 9. 
perspectives competed and coexisted in the "city of the future," they forged coalitions and constructed arguments that still influence bilingual education debates today. Language learning is a lens to examine how each generation of reformers and immigrants shaped questions of assimilation and ethnic identity.

This article explores citizenship's multiple meanings in Los Angeles by describing five different types of Americanization, or immigrant education, in the city of angels from 1910 to 1940. It begins with the settlement house model of reforming immigrant neighborhoods, as outlined in the California Home Teacher Act of 1915, written by Mary Gibson, a Progressive Era leader who had left LA's settlement houses to teach in Mexico before returning to write the legislation. A second Americanization model, the Los Angeles Diploma Plan, was developed by male administrators who received public salaries and infrastructure unavailable to the settlement women who volunteered as Home Teachers. When the school district launched the Diploma Plan's "School of Citizenship for Naturalization" in 1927, it declared that Los Angeles was the first city to empower teachers to naturalize foreigners who passed their citizenship tests. The Diploma Plan also received more school district support because, unlike the Home Teacher Act, it focused nearly exclusively on naturalizing white immigrants from European countries.

Such racialized restriction motivated the city's Mexican and Japanese communities to devise their own agendas in a third type of immigrant education that we might call transnational - that of language or consulate schools. The Mexican Consul opened its own schools in eastside barrios, hoping the history and geography curriculum from Mexico's Office of Public Education would inspire American-born citizens to return to Mexico. At the same time, by 1930, more than a hundred schools across LA County belonged to the Southern California Japanese Language Association. Although Japanese language schools lacked official ties to the Tokyo government, both transnational models borrowed curricular traditions from their mother countries. Other immigrant educators worked more closely with Anglo Progressive Era leaders to develop a fourth model that used language and culture to promote international diplomacy. Advocates of this "building bridges" approach argued that students would become more tolerant of their Mexican American and Japanese American peers if they understood their classmates' countries of origin. In addition, immigrant students themselves advocated a fifth model of language and citizenship instruction, creating World Friendship Clubs in the 1930s and bringing phrases like "bridges of understanding" into the classroom. Students viewed this internationalist approach as a mandate to respect teenagers of color as if they were members of a high school League of 
Nations in the years between the two world wars. These five types of immigrant education showed how LA educators and students of all ethnicities shaped national debates about citizenship and transnational identities during an era of changing immigration policies between the two world wars.

The federal racialization of access to citizenship influenced these alternative approaches to Americanization at a local level. The school district's Diploma Plan was an innovative naturalization experiment-for white immigrants from European countries, and it reflected a national effort to exclude immigrants racialized as nonwhite in the 1920s. Mae Ngai and others have shown how the Johnson-Reed Act of 1924 designed national origins quotas to classify immigrants from outside of Europe and Latin America as illegal aliens. In Ozawa v. United States (1922) and United States v. Bhagat Singh Thind (1923), the Supreme Court ruled that immigrants from groups considered neither black nor white were ineligible for citizenship. ${ }^{18}$ These rulings reaffirmed previous exclusionary acts originally aimed at the Chinese and extended them to other Asians. As Natalia Molina has argued, in the decade after the National Origins Act, federal immigration officials tried to use the precedent, or "racial script," of Asian exclusion to nullify Mexican immigrants' access to citizenship as well. ${ }^{19}$ The racialization of naturalization policy certainly informed Progressive Era Angelinos as they designed Americanization curriculum like the Diploma Plan. But it also encouraged Japanese and Mexican educators to propose other immigrant education programs that challenged this racialized restriction of citizenship. The politics of exclusion shaped the development of all five models of Americanization in Los Angeles from 1910 to 1940.

\section{Part I: The Settlement House Approach to Americanization}

When the Los Angeles school district opened its immigrant education division in 1916, its chief proponents were white women with little political experience but vast ambition. As in other cities during the Progressive Era, these women became civically engaged by volunteering at settlement houses. In LA, the most prominent such leader was

${ }^{18}$ Mae M. Ngai, "The Architecture of Race in American Immigration Law: A Reexamination of the Immigration Act of 1924," Fournal of American History 86, no. 1 (June 1999), 67-92; Mae M. Ngai, Impossible Subjects: Illegal Aliens and the Making of Modern America (Princeton, NJ: Princeton University Press, 2004).

${ }^{19}$ Natalia Molina, “'In a Race All Their Own': The Quest to Make Mexicans Ineligible for U.S. Citizenship," Pacific Historical Review 79, no. 2 (May 2010), 167201; Natalia Molina, How Race Is Made in America: Immigration, Citizenship, and the Historical Power of Racial Scripts (Berkeley: University of California Press, 2014). 
Amanda Mathews Chase, one of the original evening schoolteachers at the College Settlement in 1903. This settlement house, run by collegeeducated women near the Pueblo de Los Angeles, an old area with an increasingly immigrant population, recruited volunteers like Chase to teach foreigners English. These classes became so popular that after three years the clubwomen persuaded the LA school board to take charge of the program and hire an assistant superintendent to oversee immigrant education and night schools. Those three years inspired Chase to move to Mexico City, where she taught English at a private girls' school for four years. This international experience shaped her future agenda as an author of legislation as well as English language curriculum.

Before that, however, Chase developed her authorial voice by publishing a collection of short stories about the Mexican immigrants she encountered at the College Settlement. In The Hieroglyphics of Love: Stories of Sonoratown and Old Mexico, Chase used fiction to depict the era's mundane routine of English language instruction as an episode of love and heartbreak. This created a myth that Chase would use a decade later as Angelino reformers promoted a model of Americanization that set gendered and racialized expectations toward immigrant education. ${ }^{20}$ In "Cupid and the First Reader," for example, Chase's character Ramon Morales treated the English First Reader like a "Lover's Manual of Correspondence." Although he and Guadalupe Puentes were teenagers, their long absences and illiteracy had placed them in the Foreign First Grade class. Ramon wanted to express his instant attraction to Guadalupe on paper. Since he did not know how to write in Spanish, he flipped through his First Reader for a pickup line and wrote, "The duck runs to the hen." After she wrote back, "The hen can run to the duck," they were officially in love with each other-and with Foreign First Grade. The young lovers began coming to school every day. In the final scene, the teens embrace at their desks. ${ }^{21}$

As the story continued, the racial undertones of Chase's descriptions suggested that the tale's true hero was not Ramon, or even Guadalupe, but their teacher. She used this romance to encourage

20"The College Settlement (Formerly Casa de Castelar)" in Handbook of Settlements, ed. Robert A. Woods and Albert J. Kennedy (New York: Russell Sage Foundation, 1911), 11-12; Diane Claire Wood, "Immigrant Mothers, Female Reformers, and Women Teachers: The California Home Teacher Act of 1915," (PhD diss. Stanford University, 1996), 33; Louise Cooperider, "History of the Americanization Department in the Los Angeles City Schools," (master's thesis, University of Southern California, 1934), 112.

${ }^{21}$ Amanda Mathews, "Cupid and the First Reader," in The Hieroglyphics of Love: Stories of Sonoratown and Old Mexico (Los Angeles: Artemisia Bindery, 1906), 72-82. 
regular attendance and a new interest in English vocabulary. In the final scene, the teacher separated Ramon and Guadalupe when an Italian boy complained, "I no can study when Greasers all the time hug themselves." So she "punished" the lovers by making them skip recess and copy "The little hen flew to the duck" twenty times! ${ }^{122}$ In Chase's imagination, apparently, two Mexican immigrant teenagers could not fall in love without the aid of a white teacher and, of course, her English First Reader. The fictional teacher did more than sympathize with her students; by providing them with the skills to learn English, she had given them the key to happiness. In the end, when that happiness aroused reproach from a European immigrant student, the settlement woman believed she was the only character equipped to resolve the racialized conflict.

Chase's attitude about language instruction grew more romantic during her four years teaching English in Mexico City. When she returned, College Settlement patrons recruited Chase to put her curriculum into legal language. California's Americanization efforts launched when the state legislature approved the Home Teacher Act in 1915, which authorized local school districts to hire home teachers to work with schools in immigrant areas. Many school boards resisted the idea, and Los Angeles only "hired" Chase when the Daughters of the American Revolution offered to pay her salary. By 1921, LA had 108 home teachers, more than twice the faculty of any other city. Home teachers were like traveling settlement house workers: they would conduct home visits during the day and hold evening classes to teach immigrant mothers how to make "American" homes. "We have ignored the natural home-maker and yet tried to Americanize the home," Chase explained. "The home teacher, like the family doctor and the family pastor, is to be a real and intimate possession of the family." 23 She wanted other progressive women to serve as home teachers because, while immigrant children assimilated at school and their fathers adapted at work, there was no institution to assimilate mothers. In this model of Americanization, settlement workers would teach immigrant mothers how to meet the gendered and racial expectations of white womanhood in the Progressive Era.

\footnotetext{
${ }^{22}$ Ibid

${ }^{23}$ Ethel Richardson, "Program Reports of the Assistant Superintendent of Public Instruction," April 1, 1921, Records of the California Department of Industrial Relations, Division of Immigration and Housing, Bancroft Library, UC Berkeley carton 92, folder 11 (hereafter CCIH Records); Wood, "Immigrant Mothers, Female Reformers," 33; Amanda M. Chase, "Working Plans for the Home Teacher," in The Home Teacher: The Act, with a Working Plan and Forty Lessons in English (Sacramento: Commission of Immigration and Housing of California, State Printing Office, 1916), 7-9.
} 
Chase's most innovative ideas attempted to merge her expertise in English language instruction with the ideals of Americanization. She proposed that all schools in immigrant neighborhoods acquire a "school cottage" to serve as "a model American home, small but complete, attractive, but simple and inexpensive." These cottages would supply immigrants with tangible images of American values, such as hygiene and sanitation. Chase advised home teachers to visit pupils' homes on Friday field trips-under the guise of a practice social call, she urged the teachers to inspect the homes and compare their upkeep with the school cottage. Even more persuasively, she proposed English lessons that would teach immigrant mothers the vocabulary of the Americanized life they were meant to live. Chase advised teachers to "be live, practical, interesting, even dramatic" as they led language lessons about groceries, household activities, and clothing. ${ }^{24}$ Reasoning that immigrant mothers would want to learn English vocabulary they could apply in their daily activities, she advised home teachers to focus on the practical, homemaking aspects of Americanization.

Chase's English curriculum conveyed the type of Americanization she wanted home teachers to model, and it reflected her racial assumptions as well. When she gathered mothers in her classroom, her ninth English lesson taught them to say, "I cook the eggs. I wash the dress. I iron the dress. I sweep the floor. I mop the floor. I dust the chairs." But Chase was less confident about the success of such English instruction. In 1921, she complained that, even if home teachers "talked cleanliness, hygiene, school attendance, thrift, and adult education 'up one street and down another," immigrant mothers resisted most efforts to change their routines. ${ }^{25}$ By starting at the Amelia Street School, near her old College Settlement, the school's sheer diversity presented a challenge. Amelia Street's student population was "one-half Mexican, a third Japanese, while the remaining one-sixth compris[ed] Italians, Arabians, Syrians, Poles, Spaniards and Negroes." ${ }^{26}$ Chase enrolled almost ninety mothers for her courses in English, singing, patriotism, sewing, and cooking, which met twice a week for Mexican mothers and once a week for Japanese. But she was lucky if fifteen mothers came to class. This lack of interest may have stemmed from Chase's efforts to cram other assimilation activities into her language classes. ${ }^{27}$

${ }^{24}$ Chase, "Working Plans for the Home Teacher," 9-12.

${ }^{25}$ Amanda M. Chase, "Ninth Lesson," in Primer for Foreign-Speaking Women, Part I (Sacramento: California State Printing Office, 1918), 15.

${ }^{26}$ Amanda M. Chase, quoted in Wood, "Immigrant Mothers, Female Reformers," 57.

${ }^{27}$ Amanda M. Chase, "Home Teaching Experiences II," Los Angeles School Fournal 5, no. 10 (Nov. 14, 1921), 5. 
While the mission of the Home Teacher Act was Americanization, its advocates also hoped to create professional titles for progressive women. The bill's co-author joined the state Commission on Immigration and Housing, and Chase's other associates rose to become Los Angeles' first Director of Immigrant Education and assistant superintendent at the State Department of Education. They spent as much effort training home teachers as they did teaching English to foreigners. In 1920, they convinced the University of California to offer home teacher training courses taught by John Collier, a prominent progressive who would become the longest-serving director of the Bureau of Indian Affairs under Franklin Roosevelt. Collier taught Americanization courses across the state, certifying hundreds of white women as home teachers. His student teachers wrote hundreds of blue book exams describing community organizations they worked for and immigrants they taught. ${ }^{28}$

These blue books are a new set of sources that reveal the range of opinions progressive reformers held about nonwhite immigrants. They are different from the more documented "Survey of Race Relations," the life histories of Asian Americans compiled from 1924 to 1927 by sociologist Robert Park that, Henry Yu has shown, catered to Park's theory that there was a four-stage cycle of race relations. In contrast, Collier's blue books were written in 1920 by female teachers unfamiliar with the ideas Park had yet to publish. ${ }^{29}$ Vicki Ruiz has argued that, in reading such sources, historians must "sift through the bias, the self-congratulations, and the hyperbole to gain insight" into immigrant lives. Indeed, there are glimpses of immigrant voices beneath the reformers' words. ${ }^{30}$ However, in describing their students, the home teachers invariably revealed more about themselves. Some of them, like Druzilla Mackey, followed in Chase's footsteps and shuttled between the schools of Los Angeles and Mexico City.

Mackey's blue book shows how home teachers learned from their students. Her career was certainly informed by her early experience in Boyle Heights in East LA. Her exam began by explaining that "since our neighborhood is composed of Mexicans, Italians, Germans, Armenians, Syrians, Japanese, and Negroes, the process of community

${ }^{28}$ Mary Gibson to Henry Norton, Aug. 8, 1919, Henry Norton to Mary Gibson, Oct. 7, 1919, and Mary Gibson to Simon Lubin, Nov. 10, 1919, carton 1, folders 15-16, CCIH Records. Gibson was the educational commissioner who insisted on hiring Collier. She was also the author of the California Home Teacher Act in 1915.

${ }^{29} \mathrm{Yu}$, Thinking Orientals, 40-41.

${ }^{30}$ Ruíz, "Dead Ends or Gold Mines?", 298. 
organization must be slow." ${ }^{11}$ Before her first class, Mackey met with other agencies in Boyle Heights and asked how she could "plan English lessons which would teach the people the use of all the agencies." But she quickly learned that students themselves wanted to create the curriculum, noting that "young people asked repeatedly for classes of their own." 32 Although Mackey's limited funds meant she "could offer only classes in Elementary English for adults," she helped the immigrant teens organize a local boys' club and girls' club. She was impressed when the girls' club took "leadership in community singing and dramatic entertainments" to raise money for the additional classes. ${ }^{33}$ Mackey moved to rural Orange County shortly after writing this exam in 1920, but her two years in Boyle Heights taught her to trust the immigrants she worked with.

Mackey's career after Collier's class reflects the internal contradictions for Americanization teachers. The California Fruit Growers Exchange recruited Mackey to organize classes for migrant camps in the orange groves of La Habra and Fullerton. Although she was serving the agriculture industry's economic interest, Mackey "chose to live in one of the houses supplied by the fruit growers." ${ }^{34}$ She persuaded the fruit growers to pay for evening classes, offer a well-baby clinic, and build a meeting hall, where migrant workers gave musical performances that left progressive reformers impressed by the "unusual talent among the Mexican people." 35 Mackey was so inspired that she visited Mexico City in the summer of 1925 . There she met a university-trained Spanish instructor who had left the capital to work in "the mountains where nobody could read or write." 36 Mackey described this teacher to her LA colleagues as "Mexico's Amanda Chase." Even harsh critics of Orange County's migrant labor camps, such as Gilbert Gonzalez, have praised Mackey for founding six Americanization centers by 1930 . Although the fruit growers' curriculum taught men the words for menial tasks ("to prune," "to snip"), Mackey made the centers safe spaces where workers could speak in Spanish about leaders like Benito Juarez and Abraham Lincoln. ${ }^{37}$ Mackey's myriad teaching strategies reflected respect for Mexican

${ }^{31}$ Druzilla Mackey, “A Community Organization I Have Known” (Economics 89) July 9, 1920, carton 93, folder 11, CCIH Records.

${ }^{32}$ Ibid.

${ }^{33}$ Ibid.

${ }^{34}$ Cooperider, "History of the Americanization Department," 56-58.

${ }^{35}$ Druzilla Mackey, "Impresiones de Mexico," Community Exchange Bulletin 4, no.

1 (Nov. 1925).

${ }^{36}$ Ibid.

${ }^{37}$ Ibid. 
migrants and their culture while also accepting the reality that her job was to teach English to manual laborers. Although they taught students who were systematically denied access to naturalization, progressive educators like Druzilla Mackey and Amanda Chase developed a range of Americanization approaches to assimilate Mexican migrants to localized conditions. ${ }^{38}$

\section{Part II: The Diploma Plan Approach to Citizenship Education}

While Chase lobbied the legislature to pay home teachers, teacher Charles Kelso redefined the target population for the school district's fledgling citizenship department. Like Chase, he had taught in other countries. Kelso's career began in India, where a Methodist bishop asked him to teach at the Calcutta Boys' School. From there, he moved to Singapore to head the Anglo-Chinese school for four years. This experience abroad led him to graduate studies in comparative religion and education. Then Kelso came to LA, where he became the city's first official citizenship instructor in 1912. Fifteen years later, he had created his own bureaucracy while Chase was still fighting for home teacher salaries. Both teachers believed they had a moral obligation to teach foreigners how to benefit from American society.$^{39}$ But, while Chase sent teachers into LA's nonwhite communities, Kelso concentrated on European immigrants. Despite teaching non-English students overseas, he supported the Englishonly approach endorsed by Theodore Roosevelt:

We have room but for one flag ... we have room but for one language here and that is the English language, for we intend to see that the crucible turns our people out as Americans and of American nationality, and not as dwellers in a polyglot boarding house. ${ }^{40}$

Like the former US President, Kelso envisioned room for only one language when he created the Los Angeles Diploma Plan, an Americanization curriculum that received much more support than

${ }^{38}$ Mackey was one of many progressive Angelinos who collaborated with Mexico's revolutionary rural educators in the 1920s. See Flores, Backroads Pragmatists; Gilbert G. Gonzalez, Labor and Community: Mexican Citrus Worker Villages in a Southern California County, 1900-1950 (Urbana: University of Illinois Press, 1994), 122-132.

${ }^{39}$ Asbury A. Bagwell, "The Los Angeles Diploma Plan of Naturalizing the Alien: A Comparison of the Los Angeles Diploma Plan with Certain Other American Naturalization Methods in the Light of the Social Process of Assimilation and Socialization," (master's thesis, University of Southern California, 1929), 140-146.

${ }^{40}$ Harry Shafer, "Naturalization," Los Angeles School fournal 2, no. 29 (March 23, 1919), 465. 
the Home Teacher Act. In 1912, the man who had taught in India and Singapore began working at LA High School by day while overseeing the campus's "social center work" at night. Once immigrants in the evening school classes showed proficiency in English, they took Kelso's course on American government to prepare for the naturalization exam in federal court. Of course, those exams were off limits to Asian immigrants, as the Supreme Court rulings in Ozawa and Thind confirmed. Although his initial lessons were little more than tutoring to the test, Kelso became more attached to these citizenship classes than he was to LA High School. Ironically, some of the progressive women who sponsored the Home Teacher Act helped Kelso conceive of the Diploma Plan. They even introduced him to a superior court judge who they knew would approve of the proposal. Although he later argued that his citizenship work belonged in a different department than the home teachers, Kelso's agenda came from collaborating with LA's most prominent Americanization advocates. ${ }^{41}$

Kelso's influence enabled the Diploma Plan's emphasis on citizenship to supersede the earlier emphasis on Americanization in three ways. First, Kelso created a fifteen-lesson curriculum that fulfilled the city's citizenship requirements. Second, by 1915 he convinced the school district to create a new citizenship department, under his leadership, with the authority to naturalize immigrants. Third, in 1928 he converted an old elementary school building into a new "School of Citizenship for Naturalization." While the Diploma Plan made citizenship classes a direct path to naturalization, it also defined the primary purpose of Americanization classes as English instruction. This language requirement segregated the two models of immigrant education by race. While the Home Teacher Act of 1915 offered a variety of services to women classified as nonwhite and non-American at the height of the Progressive Era's immigration wave, Kelso's school made citizenship courses more racially exclusive four years after Congress passed the restrictive National Origins Act of 1924. ${ }^{42}$

In contrast to the Home Teacher Act, whose supporters published numerous articles, the Diploma Plan's central document was the physical facility that became the Citizenship School in 1928. Sitting on a tree-lined street, the two-story building represented the triumph of Progressive Era bureaucracy. With its chain link fence and picture windows, the school enjoyed the amenities that middle-class Americans were supposed to want for their own homes. Diploma

\footnotetext{
${ }^{41}$ Bagwell, "Los Angeles Diploma Plan," 106-116, 122-123, 140, 142-146.

${ }^{42}$ Bagwell, "Los Angeles Diploma Plan," 1, 82, 108; A. A. Bagwell, "Local Courses Boon to Aliens," Los Angeles Times, Aug. 21, 1927, B2.
} 
Plan graduates, the school walls suggested, did not simply wave flags and read speeches; they were active citizens steeped in the nation's history and prepared to vote. Male educators awarded more pomp and circumstance to the Citizenship School's inauguration than they did to 350 recent graduates who had taken the oath of naturalization in federal court a few weeks earlier. This showed the school district's shift in emphasis from the Americanization of children from Mexico and Japan to the naturalization of adult migrants from European, English-speaking nations. ${ }^{43}$

The Diploma Plan's only records were written by a biased source, Asbury Bagwell, who was teaching citizenship classes when he filed his master's thesis at the University of Southern California (USC) in 1929. Bagwell called Kelso the "Father of the Diploma Plan"-he also surveyed Americanization teachers in sixty cities and, unsurprisingly, concluded that LA's education policy was superior because of its stricter requirements for naturalization and English language ability. No other city empowered its teachers to determine whether or not immigrant adults were worthy of citizenship and the right to vote. Bagwell boasted that more than twenty thousand immigrants had earned citizenship in the program's first twelve years, but he added that LA had nearly a hundred and fifty thousand "foreign born white men and women of voting age." This low naturalization rate was a point of pride for Bagwell, who said:

No effort is made to "drum up" students for the citizenship classes. ... Indeed the entire enrollment is made up of those who have applied for naturalization and have been sent by the naturalization director to the citizenship school. ${ }^{44}$

The image of "aliens studying their way into citizenship" stressed that the Diploma Plan limited citizenship to a selective group of immigrants, almost all of whom were white Europeans with the resources and legal permission to undertake a process that no other city offered. Bagwell's bragging of low enrollment was the opposite approach of the city's Americanization director, a woman who proposed many methods to recruit immigrant students during World War I, even if she had to find bilingual volunteers to spread her department's agenda in other languages. ${ }^{45}$

Bagwell used Mexican students to demonstrate the differences between LA's Americanization and citizenship departments. He pointed

\footnotetext{
${ }^{43}$ Bagwell, "Los Angeles Diploma Plan," 115.

${ }^{44}$ Bagwell, "Local Courses Boon to Aliens."

${ }^{45}$ Bagwell, "Los Angeles Diploma Plan," 1, 82, 108.
} 
out that more than six thousand Mexican adults attended Americanization classes between 1926 and 1927, making up 53 percent of the evening school population. In contrast, only eight Mexicans were enrolled in the Diploma Plan, just 0.5 percent of all citizenship students. Another Diploma Plan teacher argued that Mexicans were the least likely to seek citizenship because "their easy going habits preclude the industry necessary to become a factor in the government under which they are living." ${ }^{\prime 6}$ The Diploma Plan appealed to federal officials who were looking for ways to make Mexican immigrants ineligible for citizenship. James Davis, the Republican US Secretary of Labor from 1921 to 1930, approved Kelso's proposal to promote the plan on a national scale. ${ }^{47}$ Natalia Molina has shown that Davis had wanted to include immigrants from the Western Hemisphere in the quota system of the 1924 National Origins Act. As Labor Secretary, Davis oversaw the Bureaus of Immigration and Naturalization. ${ }^{48}$ His vision of nationalizing Kelso's Diploma Plan shows how this model of immigrant education in Los Angeles supported a broader effort to deny Mexican immigrants access to naturalization.

Comparing the publicity of the Diploma Plan and the Home Teacher Act reveals two different possibilities for white teachers who created immigrant education policies in Los Angeles. Kelso and his male faculty wrote few public statements promoting the Diploma Plan, but they won private audiences with the Secretary of Labor and members of Congress far from California who supported his vision of restricting naturalization. Meanwhile, the women who worked as home teachers defended their cause in countless publications. After authoring the Home Teacher Act, Chase wrote several volumes of curriculum guides and submitted articles to state and national magazines. Her colleagues wrote grants to hire John Collier to train Americanization instructors. ${ }^{49}$ Though diploma plan teachers only published one article from 1917 to 1930, Kelso was content to sit in the school district's new citizenship department offices with his administrative funds while Chase relied on private foundations to pay her a small stipend for living expenses. Kelso quietly mimeographed outlines for his fifteen lessons on US government and history to share with his salaried

\footnotetext{
${ }^{46}$ Bagwell, "Los Angeles Diploma Plan," 39-40; William Bell, "What the Los Angeles Schools Have Done for the Alien Seeking Citizenship Training," Los Angeles School Fournal 5, no. 5 (Oct. 10, 1921), 5. Bagwell added that Americanization classes had students from forty-six different nationalities, and 2.5 percent of these students were Japanese. No Asian immigrants took citizenship classes, which had students from only twenty-four nationalities, most of which were European.

${ }^{47}$ Bagwell, "Los Angeles Diploma Plan," 122-136.

${ }^{48}$ Molina, "In a Race All Their Own'," 181-182.

${ }^{49}$ Wood, "Immigrant Mothers, Female Reformers," 79-113.
} 
citizenship teachers while some women worked as home teachers without pay. By 1931, the year of the repatriation raids, the city's superintendent of schools had canceled evening Americanization classes in the Mexican district downtown. In contrast, 1928 marked the dedication of the nation's first "School of Citizenship for Naturalization," where citizenship students from seven branch schools would come to take their citizenship exams every semester. At the ceremony, the city's new US member of Congress congratulated Kelso and proposed a new political campaign. ${ }^{50}$

Kelso was so proud of the Diploma Plan that he tried to spread it across the country. In the 1920s, he built momentum for legislation to make citizenship tests more rigorous. Kelso won endorsements from local judges and USC sociologist Emory Bogardus, who, in his 1920 book, Essentials of Americanization, declared that the Diploma Plan's three-month course gave immigrants "a heart and content to citizenship." One supporter introduced Kelso to a friend of Labor Secretary Davis. In 1928, Kelso carried the Secretary's endorsement to Washington, where he persuaded a Pennsylvania Republican to write a bill calling for "higher standards for admission to American citizenship." Democrats from immigrant strongholds in the Northeast killed the bill. But it showed the influence of an immigrant education model that authorized local school districts to restrict access to citizenship. Kelso's campaign to nationalize his city's Diploma Plan boasted that a Citizenship School would streamline the naturalization process-for white European immigrants. In effect, this discrimination against nonwhite foreigners weakened the ability of women home teachers to Americanize the same immigrant students who were barred from the Diploma Plan on the basis of race. ${ }^{51}$

\section{Part III: The Transnational Approach to Americanization}

The Diploma Plan and Home Teacher Act were pathways to citizenship offered by LA schools, but immigrants had their own ideas about Americanization and civic membership. Records of Mexican and Japanese Angelinos suggest that the school district's immigrant education experiments were not as central to their lives as reformers believed. When nonwhite immigrants discussed language learning and assimilation-in ethnic newspapers, sociological surveys, and life history

${ }^{50}$ The school of citizenship was at the old Avenue 23 School building. Kelso was fortunate to take over the facility the year before the stock market crash. Amanda Chase's Castelar Street School was one of five night school programs closed by the budget reductions of 1931. Bagwell, "Los Angeles Diploma Plan," 114-122.

${ }^{51}$ Bagwell, "Los Angeles Diploma Plan," 122-136. 
interviews - they usually spoke about their own efforts to teach the second generation their mother tongue, not English. This reflected a transnational approach to Americanization because it implied that contact with foreign languages, and even foreign governments, was central to the American immigrant experience. While Woodrow Wilson described the public schoolhouse as "the great melting-pot of America, the place where we are all made Americans of," Mexican and Japanese immigrants insisted their new language schools could become core pillars in their respective communities. ${ }^{52}$ Although these instructors found vocal supporters to endorse language preservation, immigrant desires for children to assimilate and learn English impeded supporters' intentions to establish leading institutions. These contradictory impulses were evident in Los Angeles' two largest foreign language programs for the Mexicans and the Nisei. While both experiments had flaws, Japanese language schools were able to navigate the allure of Americanization and become influential institutions, while Mexican Consulate schools rapidly dissolved as the city staged repatriation raids in the 1930s.

Comparing the Japanese and Mexican experiments in the Los Angeles context adds to the existing literature on the history of language instruction policy. Most scholarship focuses on the policies of one ethnic group. Eileen Tamura and Noriko Asato argue that government efforts to suppress Japanese language schools in Hawaii reflected the national anti-Japanese sentiment of the $1920 \mathrm{~s} .{ }^{53}$ Carlos Blanton reaches similar conclusions about the "direct method" pedagogy that Texas teachers like Lyndon Johnson used to torment Mexican students during that same decade. Other historians take a transnational approach. ${ }^{54}$ Eiichiro Azuma, for example, emphasizes that Issei (first generation) educators used language curriculum from the Japanese government to instill pride in their Japanese heritage and infuse Nisei students with "duel nationalist claims." 55 In his seminal study of Mexican Los Angeles, George J. Sánchez uses Mexican Consulate schools to explain how immigrants "became Mexican American" by

${ }^{52}$ Woodrow Wilson, The New Freedom: A Call for the Emancipation of the Generous Energies of a People (New York: Doubleday, 1913), 97. Wilson introduced this phrase in a campaign speech during the 1912 presidential election.

${ }^{53}$ Eileen Tamura, "The English-Only Effort, the Anti-Japanese Campaign, and Language Acquisition in the Education of Japanese Americans in Hawaii, 1915-40," History of Education Quarterly 33, no. 1 (April 1993), 37-58; Noriko Asato, "Mandating Americanization: Japanese Language Schools and the Federal Survey of Education in Hawai'i, 1916-1920," History of Education Quarterly 43, no. 1 (March 2003), 10-38.

${ }^{54}$ Carlos Kevin Blanton, The Strange Career of Bilingual Education in Texas, 18361981 (College Station: Texas A \& M University Press, 2004).

${ }^{55}$ Eiichiro Azuma, Between Two Empires: Race, History, and Transnationalism in Fapanese America (New York: Oxford University Press, 2005). 
combining the two national identities into a new culture. ${ }^{56}$ By placing the efforts of Mexican and Japanese educators side by side, this article examines community language schools as responses to the contradictory experiences of Americanization and racialized exclusion.

The Mexican Consulate schools probably failed to gain traction because they lacked grassroots leadership in the Eastside barrios but, like the home teacher program, they received positive coverage in the print media. In 1926, the Mexican consul in LA proposed establishing fifty schools in Southern California, funded by the Mexican Department of Education. He was endorsed by the newly established La Opinión, America's largest Spanish-language daily, which covered the schools' progress for the next four years. The consul and his backers opened eight schools across LA County by 1929, offering free textbooks and a curriculum that taught students Spanish language and Mexican history (lengua castellana e historia patria). In patriotic vernacular that emphasized Mexico's European (Castilian) ties, the consulate schools sponsored the Mexicanization of American-born children. ${ }^{57}$

Anthropologist and sociologist Manuel Gamio revealed a more complex relationship between language and assimilation in his 1931 book, The Life Story of the Mexican Immigrant. Gamio, who had emigrated to the United States from Mexico City in 1925 after denouncing corruption in the Mexican Ministry of Education, interviewed Mexican immigrants across the Southwest. In Los Angeles, he found particular interest in the consulate's school campaign.

Among the Mexican immigrants Gamio interviewed was Anastacio Cortés, a businessman from the Belvedere neighborhood who formed El Pensador Mexicano, an organization to help their children develop Mexican patriotism. An undertaker and Methodist minister, Cortés paid to build the first schoolhouse and hire the first teacher for La Escuela "Mexico" in 1926. Despite trying to make his children proud of their Mexican heritage, they had all learned English, and Cortés got angry when they did not speak Spanish at home. Gamio

\footnotetext{
${ }^{56}$ George J. Sánchez, Becoming Mexican American: Ethnicity, Culture and Identity in Chicano Los Angeles, 1900-1945 (New York: Oxford University Press, 1993).

${ }^{57}$ Stories in La Opinión included "Mas Escuelas en California," Feb. 18, 1930, 5; "50 Colegios Mexicanos en California del Sur," Nov. 12, 1927, 1; "La Escuela 'Mexico,' de Belvedere," Feb. 17, 1927, 2; "Grave Disputa en Belvedere: La Escuela 'Mexico,' en peligro de desaparecer," July 13, 1927, 1; "Ocho Escuelas Mexicanas en Los Angeles: Informe del Departamento Educativo del Consulado," Sept. 1, 1929, 1; "Tres Escuelas Para Educar 80,000 Niños," Oct. 12, 1930, 1. The Mexican Consulate in San Diego also played a role in the 1930 case to end segregated schools for children of Mexican ancestry-the first successful integration case of the twentieth century. Alicia Rivera, "The Lemon Grove Case and School Segregation in the Southwest," Fournal of Latino-Latin American Studies 1, no. 3 (April 2004), 105-118.
} 
interviewed ten other Angelinos who, according to him, refused to surrender their Mexican citizenship and wanted their children to learn Spanish. Two of the interviewees joined Cortés's El Pensador Mexicano, but the others dreamed of sending their offspring to the schools in Mexico that Gamio had criticized. In contrast, only four of Gamio's LA interviewees were happy that their children had learned English. In any case, all the immigrants Gamio interviewed had seen their children and siblings assimilate quickly. Two of them observed that Mexicans in Los Angeles were more likely to speak English than were Mexican residents in El Paso, Phoenix, and other parts of the Southwest, despite the consulate schools' presence in LA. ${ }^{58}$

In fact, the Mexican Consulate schools did not last long. Only three schools reopened in 1930, enrolling just two hundred students in a city of ninety-seven thousand Mexican-origin residents. La Opinión stopped writing stories about them to focus on the repatriation raids that deported one-third of LA's Mexican population from 1930 to 1935. Ironically, the consulate schools' demise reflected the partnership between the Mexican and US governments. While the consuls of San Diego and Los Angeles urged Spanish speakers to relocate to Mexico (even if they were American citizens), the US government did little to support those who stayed. The school district superintendent acknowledged this difficulty in 1923, complaining that it was "unfair for Los Angeles, the third largest Mexican city in the world, to bear the burden alone of taking care educationally of this enormous group.... We have these immigrants to live with, and if we can Americanize them we can live with them." ${ }^{59}$ While the LA superintendent was eager to shift the burden of educating Mexican students to the federal government, Mexican consuls were more willing to carry out national policies like repatriation. The rise and fall of consulate schools from 1926 to 1931 shows how Mexico used language education as a tool to encourage repatriation from Los Angeles in multiple ways. ${ }^{60}$

In contrast to Mexican educators who wanted their students to return south of the border, Japanese immigrants enthusiastically established their own language schools to put students on a pathway to Americanization. Mindful that exclusionary sentiments led the state legislature to restrict Japanese farm ownership in the Alien Land

${ }^{58}$ Manuel Gamio, The Life Story of the Mexican Immigrant: Autobiographic Documents (New York: Dover Publications, 1971), 50-52, 55-58, 109-111, 205-208, 237-242. Gamio's interviews were conducted in 1927 and first published in 1931.

${ }^{59}$ Mrs. Pierce and Mrs. Dorsey Discuss Matters Before the Principals' Club," Los Angeles School fournal 6, no. 25 March 5, 1923, 59.

${ }^{60}$ James William Cameron, "The History of Mexican Public Education in Los Angeles, 1910-1930" (master's thesis, University of Southern California, 1976), 39, $179-180$. 
Laws of 1913 and 1921, Japanese language schools were careful to avoid the impression that they despised the language and customs of their Anglo neighbors. This helped make Japanese language schools community institutions in LA until internment began in 1942. Comparing the longer-lasting Japanese schools with the brief Mexican Consulate schools experiment shows that these foreign language educators believed they were just as responsible for the Americanization of their community's children as the models proposed by Anglos like Amanda Chase and Charles Kelso.

Unlike the Mexican Consulate schools, which disappeared from the public record in 1931, Japanese language schools did not have an enrollment shortage. In the 36th Street school district, for example, 44 percent of the 199 Nisei attending public schools in 1927 spent their afternoons in language school. One Nisei born in Little Tokyo in 1923 remembered the language school and the public school, along with the Japanese grocery, barbershop, and mortuary, as the pillars of her neighborhood. There were thirty-five language schools in the county by 1930, from San Pedro to San Fernando, but this expansion came with some controversy. By the 1930s, they were opening so rapidly that the Japanese Chamber of Commerce proposed consolidation because they were expensive to operate and draining money from immigrant families. Despite these divisions, the schools all joined the Southern California Japanese Language School Association (SCJLSA) and shared the same structure of gathering the Nisei for a few hours every evening after public school "to instruct children in reading and the writing of the language, to make them understand daily conversations ... and to furnish the American-born children with a Japanese background." 61

But language school instructors left the meaning of "Japanese background" open for interpretation. In 1911, SCJLSA president Kohei Shimano founded the city's first language school, Rafu Daiichi Gakuen, located a few blocks from the Amelia Street School, where

${ }^{61}$ Koyoshi Uono, "The Factors Affecting the Geographical Aggregation and Dispersion of the Japanese Residences in the City of Los Angeles" (master's thesis, University of Southern California, 1927), 110-130; Sue Kunitomi Embrey, interview by Arthur Hansen and David Hacker, Aug. 24, 1973, \#1366, in Fapanese American World War II Evacuation Oral History Project: Part I, Internees ed. Arthur Hansen (Westport, CT: Meckler, 1991), 102; Diana Meyers Bahr, The Unquiet Nisei: An Oral History of the Life of Sue Kunitomi Embrey (New York: Palgrave Macmillan, 2007), 13; Tamiko Tanaka, "The Japanese Language School in Relation to Assimilation" (master's thesis, University of Southern California, 1933), 34, 39; Fumiko Fukuoka, "Mutual Life and Aid Among the Japanese in Southern California with Special Reference to Los Angeles" (master's thesis, University of Southern California, 1937), 69-70. 
Amanda Chase would become LA's first home teacher five years later. ${ }^{62}$ Shimano tried to work with the Amelia Street principal, especially after 1921, when the state legislature passed the Private School Control Law that required all language schools to only hire teachers proficient in English and to only use textbooks approved by the State Board of Education. ${ }^{63}$ So Shimano published a series of texts that expressed the Niseis' dual allegiance as Beishu Nichijûu, "primary emphasis on America and secondary on Japan." ${ }^{4}$ But after the US Supreme Court overturned the Private School Control Law in 1927, two-thirds of the schools in the SCJLSA left Beishu Nichijî and returned to the Japanese-approved textbooks, which discussed loyalty to the emperor. Shimano warned against this decision, stating that "although the moral training of the children can be greatly accomplished by the presentation of good Japanese racial traits, we must not forget that we are educating American citizens." ${ }^{55}$

Many principals did not share Shimano's sympathy for Beishu Nichij $\hat{u}$, but the SCJLSA balanced Americanization and cultural preservation more carefully than did the Mexican Consulate schools. Unlike El Pensador Mexicano, which wanted children to return to Mexico, SCJLSA policy was that "Japanese children are Americans and are going to spend all their years here, and our whole educational system must be founded upon the spirit of the public instruction of America." 66 While the Mexican Consulate created all-day schools, Japanese classes occurred on afternoons and weekends to avoid conflicts with the public schools. Despite different policies, language assimilation had similar impacts in each community. Just as Anastacio Cortés became angry when his children spoke English at home, one Nisei teenager spoke English with her friends and siblings but was careful to switch to Japanese "the minute when my father or mother should enter our presence." ${ }^{67}$ Although Japanese language schools were more popular and long-lasting than the Mexican Consulate schools, most Nisei never became proficient in Japanese. However, just as the Consulate schools reflected the Mexican government's position on repatriation, Japanese educators adopted curriculum designed to avoid further Supreme Court cases. ${ }^{68}$ These two

${ }^{62}$ Embrey interview by Hansen and Hacker, 102.

${ }^{63}$ Tanaka, "The Japanese Language School," 56-58.

${ }^{64}$ Toyotomi Morimoto, "Language and Heritage Maintenance of Immigrants: Japanese Language Schools in California, 1903-1941" (PhD diss., University of California, Los Angeles, 1989), 68.

${ }^{65}$ Morimoto, "Language and Heritage Maintenance of Immigrants," 80-93.

${ }^{66}$ Kiichi Kanzaki, California and the Fapanese (1921; reissue, San Francisco: R and E Research Associates, 1971), 20-21.

${ }^{67}$ Tanaka, "The Japanese Language School," 51.

${ }^{68}$ Morimoto, "Language and Heritage Maintenance of Immigrants," 8. 
transnational models of language instruction showed how federal policies influenced different approaches toward Americanization from Mexican and Japanese immigrants.

\section{Part IV: The "Building Bridges" Approach to Citizenship Education}

While the transnational models reacted to government policy, immigrant educators also taught the second generation to proactively participate in American society and foreign diplomacy. Between the wars, the city's Japanese and Mexican communities created their own citizenship curricula based on a foreign diplomacy model of "building bridges." The idea was that immigrant children could represent both the best of America and their ethnic heritages. These programs mixed the study of history and government with instruction in language and culture. Like their Anglo counterparts, Mexican and Japanese educators traveled overseas, worked with foreign diplomats in LA, taught students about rhetoric, and used symbols such as the flag to represent their communities. Nisei study tours, Friends of the Mexicans conferences, and oratory contests were all collaborations with Progressive Era reformers. But these events also allowed immigrants themselves to develop their own notions about US citizenship in school settings beyond the control of administrators like Charles Kelso and Amanda Chase.

The Issei argued about whether their children would become better bridges of understanding if they went to school in Japan or America. Some wanted Nisei children to stay in California so they could learn English in the mornings at public schools and their ethnic culture in the evenings at Japanese language schools. Other Issei created a Nisei subset, the Kibei, or American-born Japanese who left their families and went to Japan for school. In the interwar years, the relative popularity of both American-based language schools and Japanesebased programs for Kibei fluctuated with the diplomatic relationship between the two Pacific powers. Ironically, while adult politics left each nation's education program in limbo, the Nisei themselves came up with their own compromise. In the 1930s, they took summer study tours to Japan to learn about their parents' culture and to make sense of their ties to each country. While the Nisei study tours stopped not long before the bombing of Pearl Harbor, their development after the mid-1920s showed how Japanese immigrants struggled to participate in the civic life of two nations. In contrast to Charles Kelso, whose overseas experience influenced his US citizenship curriculum, foreign-born Issei like Kohei Shimano took their young bridges of 
understanding abroad to secure peaceful relations between the two nations he loved. ${ }^{69}$

The textbook debate showed Shimano's desire to prove that Japanese language schools could Americanize the Nisei. He also built bridges of understanding with educators from Japan and LA, including the principal at Amanda Chase's Amelia Street School. ${ }^{70}$ He hoped this partnership would assimilate students into civic life beyond Little Tokyo. In 1915, Shimano stated that Japanese language teachers intended to serve "the Nisei who will live and work permanently here, not to those who will return to Japan." 71 He even conveyed this message to colleagues across the Pacific. In 1917, seven teachers from Japan visited Los Angeles to inquire about Nisei education. Shimano asked the Amelia Street principal to host a reception for the Japanese educators at her campus, rather than his Rafu Daiichi Gakuen School, to show the guests he was serious about Americanization. On his campus, Shimano displayed the American flag alongside the Rising Sun of Japan. When both flags were once defaced, one of his students later remembered, Shimano called a school assembly to give a "stern lecture about the care of a flag and the respect that we owed to the flag because it was a symbol of a country." 72 In drawing on the expertise of educators from LA city schools as well as Japan, Shimano coordinated a binational effort to turn Nisei students into upstanding American citizens, a collaboration that colored his approach to the Nisei study tours of the 1920s.

Issei leaders believed that, after the National Origins Act of 1924 continued to restrict Japanese immigration, sending the Nisei on educational trips to Japan was the best way to improve diplomacy and border policies. But there were different ways to organize the trips. When Shimano took fifteen language students to Japan in 1925 , he also invited Nellie Oliver, who had taught at Amelia Street in the 1890s. By 1925, Oliver was overseeing the charity-operated Stimson Lafayette Industrial Institute, which offered Americanization classes on the second floor and allowed Shimano to hold his Japanese language classes downstairs. ${ }^{73}$ Shimano hoped Oliver's voyage would show Angelino educators that Japan study tours enhanced the

\footnotetext{
${ }^{69}$ For more on "bridges of understanding" from the Japanese national perspective, see Azuma, Between Two Empires, 145.

${ }^{70}$ School News," Los Angeles School fournal 1, no. 2 (Dec. 1917), 34.

${ }^{71}$ Kohei Shimano, quoted in Yuji Ichioka, Before Internment: Essays in Prewar Fapanese American History, ed. Gordon Chang and Eiichiro Azuma (Stanford, CA: Stanford University Press, 2006), 20.

${ }^{72}$ Embrey interview by Hansen and Hacker, 106.

73 "History of Miss Oliver and the Oliver Clubs," http://www.discovernikkei. org/en/nikkeialbum/items/879/.
} 
Americanization of Nisei students and helped them become bridges of understanding with Anglos.

But Nisei students had their own agenda. One of the most ambitious study tours turned into a yearlong, trans-Pacific adventure for John Aiso, Hollywood High's most accomplished and controversial salutatorian when he graduated in 1926 at age 16. The youngster used his speaking success to build relationships with influential adults in LA, Tokyo, and Washington. Before Aiso's Washington, DC, oratorical contest trip, Japan's LA consul advised him to call on the Japanese ambassador, who sent him to meet the president of Brown. The college had previously worked with the Japanese embassy when one of its alums, Secretary of State Charles Evans Hughes, tried to repair US-Japan diplomacy after Congress passed quota restrictions in 1924. But Brown wanted to see Aiso's transcript first before he could enroll in freshman classes. Aiso ultimately earned a scholarship to Brown, but the delay gave him an opportunity for an extended Japan study tour. ${ }^{74}$ Despite the disappointment in Washington and Providence, the Nisei "silver tongue" had used his rhetorical skills to network with key figures in both the US and Japanese governments.

Aiso applied his consular connections to achieve conflicting goals that somehow satisfied his Nisei obligation to build bridges of understanding. After his graduation speech at Hollywood High, he spoke about studying Japanese with the local vice-consul, who offered him room and board in Tokyo for the following school year. With the official's aid, Aiso enrolled in a special class at Seijo Gakuen for children of Japanese diplomats returning from overseas service. But once he arrived in Japan, he learned that Brown had admitted him with a sizable scholarship. From Washington, the Japanese ambassador sent Aiso's parents a stern letter asking, "What is your son doing when I have gone to the trouble of obtaining a scholarship to Brown University for him? Get him back and have him enroll promptly."75 But Aiso stayed in Tokyo for ten months, and he likely earned the ambassador's appreciation when he convinced LA Times publisher Harry Chandler to publish a series of articles, "Impressions of Japan." Indeed, Aiso's 1927 assertion that "now is the dawn of a new Pacific era destined by Providence to engage the attention of the whole civilized world" articulated the messages that consuls conveyed

${ }^{74}$ Tad Ichinokuchi and Daniel Aiso, Fohn Aiso and the M.I.S.: Fapanese-American Soldiers in the Military Intelligence Service, World War II (Los Angeles: Military Intelligence Service Club of Southern California, 1988), 7-9.

${ }^{75}$ Ichinokuchi and Aiso, "John Aiso and the M.I.S.," 7-9. 
to Japanese language schoolteachers. ${ }^{76}$ Before he began freshman year at Brown in the fall of 1927, Aiso's actions had pleased senior diplomats in Washington and Tokyo, the capitals of both nations with which he identified. But it was his eloquent essays about citizenship in Los Angeles that had first introduced him to the consuls who made his travel and education possible.

The Mexican consuls in LA also worked with progressive Angelinos to frame the "problem" of Mexican immigration in the context of schooling. In contrast to the Consulate's failed attempt to establish its own schools in Southern California, a longer-lasting initiative began at Pomona College in collaboration with Moisés Sáenz, the Mexican Sub-Secretary of Public Education whom Manuel Gamio had denounced. At the small college in eastern LA County, Mexican diplomats and Anglo educators discussed controversial issues of the 1920s, including immigration, labor, and education. Starting in 1921, Pomona hosted nine Friends of the Mexicans conferences, which gained in popularity each year, drawing more than five hundred participants in 1929. ${ }^{77}$ Unlike John Aiso's impressive relationships, Mexican students had minimal influence at these elite exchanges. Thus, while Friends of the Mexicans conferences led to a more coordinated educational program on both sides of the border, they also left students little say in citizenship instruction and small hope of becoming "bridges of understanding."

The Mexican government's interest in the conference made this educational exchange possible. In 1926, the same official who launched the consulate school in East LA also arranged for a group of Mexican teachers to spend six weeks of summer school at Pomona for "special study of the English language and American educational methods." ${ }^{78}$ The consul also called on Sub-Secretary Sáenz to invite a Pomona administrator to Mexico. By 1928, the exchange had extended to LA schools. Angelino teachers toured schools in Mexico City, the rural countryside, and the Universidad Nacional Autonoma de Mexico. That spring, twenty-eight Mexican educators spent a week in LA, whose school system provided Spanish-speaking teachers as hostesses. The Mexican contingent mixed business with pleasure. After inspection tours of LA public schools and Spanish classes at the National

\footnotetext{
${ }^{76}$ Aiso, "As Japan Sees America."

${ }^{77}$ Merton Hill, "Conference of 'Friends of the Mexicans," Pomona College Magazine 17, no. 2 (Dec. 1928), 1. For more on Sáenz's policies in Mexico, see Flores, Backroads Pragmatists, and Mary Kay Vaughan, Cultural Politics in Revolution: Teachers, Peasants, and Schools in Mexico, 1930-1940 (Tucson: University of Arizona Press, 1997).

${ }^{78}$ James Batten, "Friends of the Mexicans," Pomona College Magazine 15 (1927), 80.
} 
Automotive, Electric, and Aviation School, they visited Hollywood movie studios and saw the San Gabriel Mission Play, a popular pastoral imagining of life in California under Spanish colonial rule. ${ }^{79}$ Pomona's summer school program and the weeklong visit to LA showed more attention to teachers working in Mexico than most home teachers gave to the immigrants who lived in the city's poorest communities. The Friends of the Mexicans conference reflected a binational effort to define Americanization as a class-based concept intended for elites on both sides of the border, not the masses they taught.

The annual pilgrimages to Pomona allowed Angelino educators to reevaluate their positions on Mexican immigration law, citizenship, and labor status. The Macy Street School principal, Nora Sterry, who also supervised home teachers, was one LA educator who defended Mexican workers against exploitation from ranchers like the Western Growers Protective Association. In lamenting the impact of migrant labor on Mexican families, she stressed the social cost of starting "foreign district" schools and hospitals and ignored the economic conditions that made growers want seasonal work. She mixed sympathy with low expectations, noting that "Mexican children have as fair intellect as other children but they are stunted mentally as well as physically by the spiritual and mental paucity of their homes." 80 The principal urged Congress to extend the quotas from the National Origins Act to restrict future Mexican migrants. This stood out at the Pomona conference because a Mexican speaker who followed her took the opposing position on naturalization classes, demanding a new form of Americanization, with "less flag-waving and less anthem-singing" and more emphasis on teaching children to be global citizens. ${ }^{81}$ But her comments showed that even home teachers who worked with immigrant mothers in intimate settings supported a systematic effort to deny Mexican Angelinos access to naturalization.

At the 1928 conference, the assistant superintendent of LA schools addressed the subject of US citizenship directly. He asserted that Californians were concerned about the nations with whom they shared a border or an ocean, mentioning Mexico as well as America's "PanPacific policies and prospects" with Japan. Unlike Issei study tour guides, the administrator had a more measured outlook on building

79"Mexican Educators to Be Entertained," Los Angeles School Fournal 11, no. 34 (May 14, 1928), 13-14.

${ }^{80}$ Nora Sterry, quoted in "Friends of the Mexicans," Community Exchange Bulletin 8, no. 2 (Dec. 1929), 35-37.

${ }^{81}$ Alberto Rembao, "What Should Be Done for Juan Garcia?", Pomona College Magazine 17, no. 3 (Jan. 1929), 145-148. 
bridges of understanding, noting that from World War I to the National Origins Act, "periods of fairly friendly feeling have on a few occasions been interrupted by more hostile attitudes." 82 This described the Mexican border, but the superintendent showed interest in Spanish-speaking views about US citizenship at previous conferences. After reading reports by Diploma Plan teachers criticizing Mexican American patriotism, he had persuaded the Friends of the Mexicans officers to consider "why so few Mexicans have any desire to become American citizens." In emphasizing that migrant workers lacked interest in citizenship, he accepted the conference consensus that "Mexicans entered the United States for economic reasons, but nationally and racially remain Mexican in most cases." ${ }^{33}$ While the Pomona conference invited teachers, diplomats, and politicians from Mexico, it did not give agency to the migrant workers who sent their children to LA schools. However, by implying that Mexicans themselves bore responsibility for low naturalization rates, the assistant superintendent further justified a broader effort to restrict Mexican American citizenship applications.

\section{Part V: The "World Friendship" Approach to Citizenship Education}

While the school district promoted Charles Kelso's Diploma Plan by opening the "School of Citizenship for Naturalization" in 1927, other Angelinos introduced a "world friendship" model of citizenship instruction after World War I. Teachers wanted youths to build bridges of understanding between nations in LA classrooms. This development reflected the city schools' shift from a few reformers with political influence to a more diverse population of students with their own ideas about education. Other scholars have examined the Anglo teachers who created "internationalism studies" and "cultural gifts" curricula in the 1930s. This article concludes by placing world friendship references from the Los Angeles School Fournal in a transnational context. Just as Nisei like John Aiso applied their Japan study tours to diplomatic efforts as bridges of understanding, Angelino educators used their own experiences abroad to shape a new emphasis on global current events during the buildup to World War II. The rise of World Friendship Clubs as an alternative to the Diploma Plan reflects immigrant education's transition from the Progressive Era's emphasis

${ }^{82}$ Harry Shafer, "1928 'Friends of the Mexicans' Conference," Community Exchange Bulletin 7, no. 4 (March 1929), 9-10.

83 James Batten, "Letter to the Editor," Community Exchange Bulletin 6, no. 1 (Oct. 1927), 41 . 
on reform to New Deal liberalism that developed in multiethnic districts like East LA. ${ }^{84}$

The Fournal linked world friendship to the overseas experiences of Angelino educators in a 1925 issue dedicated to "Education for World Relationships." One writer reframed Americanization work as "brotherhood making or brotherization," suggesting that teachers now looked at immigrant students as representatives of their parents' homeland rather than as young Americans, turning their classrooms into international summit meetings. ${ }^{85}$ Another article, "Teaching Brotherhoodness," explained that the term had come from the 1923 World Conference on Education in San Francisco, where a Chinese delegate said that "reading and language work give the resourceful teacher a chance to impart the sense of world relationship" on foreign students. ${ }^{86}$ The Fournal touted internationalism to teachers by promoting the PanPacific Association for Mutual Understanding, a new group that hosted "monthly travel dinners" and arranged lectures with LA consuls from Pacific Rim countries, including Mexico and Japan. The Pan Pacific Association wanted schools to have "ample provision for the teaching of the Oriental languages, training for diplomatic service and commercial leadership." ${ }^{7}$ A story on the next page reported the latest meeting of the League of Nations, which was promoting its own world peace curriculum. Various forms of world friendship courses were not unique to Los Angeles, or even to the United States, but LA teachers used these internationalist ideas to endorse language and social studies content that addressed the city's immigrant populations. ${ }^{88}$

${ }^{84}$ For a description of "internationalism studies," see Mark Wild, "So Many Children at Once and so Many Kinds': Schools and Ethno-racial Boundaries in Early Twentieth-Century Los Angeles," Western Historical Quarterly 33, no. 4 (Winter 2002), 453-476. See also Burkholder, Color in the Classroom; Selig, Americans All.

${ }^{85}$ Emma Raybold, "Brotherization," Los Angeles School fournal 8, no. 9 (Nov. 2, 1925), 16.

${ }^{86}$ Mary Foster, "Teaching Brotherhoodness," Los Angeles School fournal 8 no. 9 (Nov. 2, 1925), 10.

${ }^{87}$ Alice Wells, "The Pan-Pacific Association for Mutual Understanding," Los Angeles School fournal 8 no. 9 (Nov. 2, 1925), 18.

${ }^{88}$ This "Education for World Relationships" issue of the Los Angeles School Fournal also included articles titled "Modern Foreign Language Study" and "The League of Nations." While historians have examined world peace curriculum between the wars elsewhere, LA educators argued that "the first club of that nature in any high school of the country" originated in 1915 at Hollywood High School (John Aiso's future alma mater). See "The Federation of World Friendship Clubs," Los Angeles School Fournal 10, no. 28 (March 21, 1927), 76; Selig, Americans All; and Ken Osborne, "Creating the 'International Mind': The League of Nations Attempts to Reform History Teaching, 1920-1939," History of Education Quarterly 56, no. 2 (May 2016), 213-240. 
It was ironic that World Friendship Clubs became more popular in Los Angeles schools in the Progressive Era. The idea that students could form a miniature League of Nations assumed that schools in immigrant districts were integrated. In fact, the interwar period was an era when Mexican students were sent to segregated schools across Los Angeles and Southern California. Yet Anglo educators emphasized the few racially diverse schools in Central and East LA. One of these exceptions, Hollywood High School, founded the Cosmopolitan Club in 1915, "the first club of that nature in any high school of the country." ${ }^{9}$ The history department chair arranged evenings at Japanese, Chinese, Italian, and French restaurants, where Hollywood students dined and debated with the corresponding consuls. This experience was not typical of Mexican students in the 1920s, but some Americanization advocates argued that world friendship was an important alternative to segregation. The author of the "Brotherization" article lamented the presence of "so-called Mexican schools" in LA. Further, focusing on world relations led teachers to discuss the cultures of other countries, prompting the Foumal to ask, "Are we educating Mexicans to be Mexicans, or are we educating them to be Americans?" 90 The world friendship model offered teachers an international construct that included Mexican students in conversations about citizenship, even as Diploma Plan instructors were adhering to a curriculum that worked to make them ineligible for naturalization.

By the 1930s, immigrant students had reinvented World Friendship Clubs as a newer alternative model that accounted for recent events that were leading the world closer and closer to global war. It was ironic that the Hollywood High teacher explained that his original Cosmopolitan Club had been renamed "World Friendship" in a School Fournal issue devoted to the topic of "Mexican Education." The teacher was proud that fifteen city schools had formed World Friendship Clubs by 1928, but students of color noted that "world relations" classes did not fully contextualize the ethnic diversity of the school district's population. ${ }^{91}$ World relations classes in the 1920 s had similar purposes to ethnic studies curricula today, but they emphasized the history of nations like Mexico and Japan rather than Mexican and Japanese Americans in LA life. One Nisei student from Chase's Amelia Street School recalled:

People say that things like Chicano studies or black studies are innovations in education. We had all that ... On May 5 there was Cinco de Mayo and

\footnotetext{
${ }^{89}$ Raybold, "Brotherization," 19.

90 "The Federation of World Friendship Clubs," 76.

${ }^{91}$ Raybold, "Brotherization," 19.
} 
Japanese Boys' Day, and they used to have people come in from the community or have kids from the school to do these programs. We actually had a cultural program all year round. ${ }^{92}$

The two holidays that fell on May 5 fit the world relations format of using ceremonies to study other nations. However, in emphasizing the ethnic heritage of Mexican and Japanese Angelinos, this curriculum neglected the fact that these children were also American citizens. When the World Friendship Club came to Roosevelt High in East Los Angeles in 1931, Mexican and Japanese students worked with sympathetic teachers to ensure that they designed language lessons that celebrated their students' cultures from an American perspective. ${ }^{93}$

Roosevelt High was located just east of the LA River in Boyle Heights, the city's most diverse district. Abandoning the Cosmopolitan Club title that Hollywood High had introduced in 1915, Roosevelt's Mexican and Japanese students referred to the World Friendship Club as the Peace Club in 1931. Unlike Hollywood High, whose principal once told John Aiso to drop out of the national oratorical contest, Roosevelt opened doors to successful students of color. In the 1930s, several student body presidents showed off their citizenship in times of economic and diplomatic crisis. Arthur Takemoto, the Nisei president in 1939, called his weekly column in the Rough Rider newspaper the "Fireside Chat." Hugh Acevedo, the 1935 vice president, joined the school's Reserve Officers' Training Corps (ROTC). But Acevedo was also the only Mexican or Japanese officer of the World Friendship Club, which had mostly white and Jewish students during the Depression. A 1936 survey estimated that 28 percent of Roosevelt's students were "American" and 26 percent were Jewish, but 24 percent were Mexican and 6 percent were Japanese. The school's multiethnic makeup shaped the Peace Club in other ways during the 1930s, when multiple Rooseveltians won LA's annual Federation of World Friendship Clubs Oratorical Contest. ${ }^{94}$

${ }^{92}$ Embrey interview by Hansen and Hacker, 102.

93 "Our Contributors: 'Mexican Education' Issue," Los Angeles School Fournal 11, no. 34 (May 14, 1928), 12; "World Friendship Club Organized in 1931," Roosevelt [H.S.] Rough Rider, April 26, 1935, 1. The author thanks Mr. Joseph Zanki Sr., retired Roosevelt High School (in Boyle Heights) history teacher, for sharing old volumes of the Rough Rider, hereafter referred to as the Zanki Papers. Ethnic studies became a national issue in 2010 when the state of Arizona banned ethnic studies from Tucson public schools. See Mari Herreras, "Class and Controversy: Tucson High's Ethnic Studies Students Wonder Why Tom Horne Won't Leave Them Alone," Tucson Weekly, May 27, 2010, http://www.tucsonweekly.com/tucson/classes-andcontroversy/Content?oid $=1998398$.

${ }^{94}$ Arthur Takemoto, "Fireside Chat," Roosevelt [H.S.] Rough Rider, Nov. 2, 1939, 2; "Hugh Acevedo Elected to Vice Presidency," Roosevelt [H.S.] Rough Rider, June 7, 1935, 
Students recruited teachers to participate in Peace Club events by inviting them to speak about their travels around the world. The club's first sponsor in 1931 was Mrs. Helen Bailey, a social science teacher who summered in South America. She left the faculty after marriage, but returned to address the World Friendship Club in 1934, when she told students about her experiences in Mexico. Bailey brought paintings to her talks and wore "a Mexican national costume which was made for her by her Mexican friends." 95 She compared urban and rural living conditions and hinted at her own urban bias by explaining "how the Mexican federal government is starting a plan to educate the Aztec Indians who still speak the Aztec Indian language and are many years behind times." ${ }^{96}$ By expressing her belief that indigenous Mexicans could learn other modern languages like Spanish, Bailey implied confidence in the ability of the immigrant students in Roosevelt's World Friendship Club to learn American culture and become productive citizens of the United States and the world. ${ }^{97}$

Language learning had a different political context when a Latin teacher, Miss Ida Bel Eby, addressed the World Friendship Club in 1935, sharing her experience teaching English in Japan. After visiting a Nisei student at college and touring Tokyo, Eby decided that Japan's "scenery was very interesting and like that of England." In concluding that "the English language was quite common in Japan," 98 Eby informed the Japanese Club that learning English was important for Nisei no matter where they lived. It is important to note that Eby made language a priority when she spoke to the Japanese club but drifted to cultural diplomacy when she told the Peace Club about her summer in Europe four years later. In 1939, on the eve of the war, Eby shared her observations of Fascist Italy, where the trains were overcrowded, the hotels in bad condition, and Mussolini was hiring "cheering squads" for public parades. ${ }^{99}$ Roosevelt's lone Latin teacher showed how the war had changed her ideas about Americanization and citizenship curriculum. When addressing the Japanese Club in 1935, Eby

4; "Albert Teplitz to Preside at World Friendship Aud," Roosevelt [H.S.] Rough Rider, Nov. 8, 1934, 1 (Zanki Papers).

95 “Mrs. Bailey Gives Talk," Roosevelt [H.S.] Rough Rider, Oct. 27, 1933, 4 (Zanki Papers).

96"Mrs. H. Bailey Talks to Club," Roosevelt [H.S.] Rough Rider, Nov. 10, 1933, 1

(Zanki Papers).

97 "Peace Club Meets Today," Roosevelt [H.S.] Rough Rider, Oct. 11, 1934, 4 (Zanki Papers).

98 "Nippon Club Hears Talk," Roosevelt [H.S.] Rough Rider, March 15, 1935, 1

(Zanki Papers).

99 "World Friendship Hear Miss Eby Talk of European Tour," Roosevelt [H.S.]

Rough Rider, Oct. 5, 1939, 1 (Zanki Papers). 
emphasized that Nisei students needed to learn English before they could participate in advanced discussions of democracy like the ones she had about Italy. This sent a message that, while Nisei students might be able to learn English and assimilate into American life, they did not yet deserve the same access to civic participation that white students enjoyed. Faculty like Bailey and Eby brought their own assumptions of Americanization and civic membership to their meetings with the Peace Club.

But students also shaped how Roosevelt teachers came to understand the world friendship model of citizenship education and the difficult process of naturalization. The faculty expert on citizenship was Asbury Bagwell, who had written the history of the Diploma Plan in 1928. Upon arriving at Roosevelt, Bagwell started speech competitions in his economics classes, which the Rough Rider called "an unusual and effective method of teaching." 100 In 1933, Bagwell's students (mostly Jewish and Nisei) debated an early New Deal program, the controversial National Recovery Administration. This was consistent with the Diploma Plan's dedication to curriculum about the Constitution and the branches of government. However, as he got to know his new students at Roosevelt, Bagwell began to address topics other than domestic politics. In 1934, he gave two talks on the "Economic Situation in Cuba Before and After the Revolution" to the honors society and to Roosevelt's new Latin American History class. ${ }^{101}$ In 1935, he was the guest speaker at two World Friendship Club meetings. When discussing current events with the Peace Club, he addressed upcoming World Friendship Club resolutions about international disarmament. ${ }^{102}$ This suggests that the economics teacher considered Cuba and peace treaties to be as important as the New Deal or the naturalization policies he had helped to change in implementing the Diploma Plan the previous decade. As a teacher in Los Angeles' most diverse high school in the 1930s, Bagwell began to see students as global citizens.

Bagwell's transition from Charles Kelso's citizenship department to the World Friendship Club demonstrates the shift in Los Angeles' immigrant instruction experiments. Bagwell began teaching white immigrants in evening citizenship classes in the 1920s to supplement

100 “A. Bagwell Starts New NRA Contest," Roosevelt [H.S.] Rough Rider, Oct. 20, 1933, 1 (Zanki Papers).

101 "Mr. A.A. Bagwell to Speak to Aldebarans on Cuban Situation," Roosevelt [H.S.] Rough Rider, Nov. 24, 1933, 1 (Zanki Papers).

102 "Mr. A.A. Bagwell Speaker at Social Science Class," Roosevelt [H.S.] Rough Rider, June 1, 1934, 1; "Friendship Club Holds Meeting," Roosevelt [H.S.] Rough Rider, Jan. 31, 1935, 1; “Teplitz to Lead S'35 Peace Club," Roosevelt [H.S.] Rough Rider, Feb. 15, 1935, 1 (Zanki Papers). 
his job at Manual Arts High School, where he had judged the Constitutional oratorical contest in 1927, a year after the John Aiso controversy. His transfer to Boyle Heights represented a new generation of Angelino educators. These New Deal teachers were not like Kelso, the missionary who naturalized only white, English-speaking students, or Amanda Chase, the romantic settlement house worker who returned from Mexico to author the Home Teacher Act. They were secular savants who explored the Pacific Rim. Roosevelt High teachers summered in Asia and the Americas and shared travel stories with their students.

In contrast to Chase's stern portrait of illiterate immigrant teenagers in 1906, Mrs. Bailey made her 1932 lecture fun, organizing personal photos into "a motion picture [to] depict the customs, life, and habits of the Mexican people." ${ }^{103}$ She had a soft spot for the kids of East LA, she admired the countries they came from, and she empowered them to take charge of their own education. The rise of World Friendship Clubs in the 1930s showed how students were altering the direction of LA's citizenship curriculum. After Bagwell moved to the city's most ethnically diverse high school, the chief advocate of the Diploma Plan's approach to restrict naturalization placed citizenship in a more global context. Angelino educators like Bailey and Bagwell often mediated tensions between American ideals and the actual political treatment of their immigrant students during a period of Mexican deportation and imperial competition with Japan..$^{104}$

\section{Conclusion: Multiple Education Models Made Citizenship More Inclusive}

This article has examined five models of language and citizenship education to understand how the meanings of Americanization and civic membership in Los Angeles schools changed between the two world wars. In the first two models, run by settlement house workers and "Diploma Plan" teachers authorized to naturalize any white immigrant who passed their classes, Anglo educators created a curriculum that gave them opportunities to carry out federal policies that restricted

\footnotetext{
103 "Mrs. Bailey Gives Talk," Roosevelt [H.S.] Rough Rider, Oct. 27, 1933, 4, (Zanki Papers).

${ }^{104}$ "Cancer Claims Life of ELAC's Helen M. Bailey," Los Angeles Times, Sept. 30, 1976, SE4 (Zanki Papers). In the 1930s and 1940s, LA educators became very involved in debates about Japanese internment, Mexican migrant workers, and the supposed threat of so-called juvenile delinquents after events like the Zoot Suit Riots. The author addresses these issues in his forthcoming monograph, Active Voices: Language Education and the Remaking of American Citizenship in Los Angeles, 1900-1998.
} 
further immigration by race, such as the National Origins Act of 1924 and two Supreme Court cases that ruled Asian immigrants ineligible for citizenship. These racialized restrictions constrained the Americanization experience for non-European immigrants on the West Coast. In response, the Mexican and Japanese communities in Los Angeles launched a variety of language instruction experiments that demonstrated their many contributions to American society as engaged citizens with useful access to transnational networks. Scholars such as Diana Selig, Zoë Burkholder, and Jeffrey Mirel have argued that the shifting emphasis in Americanization and citizenship courses between the world wars represented a process of cultural negotiation between progressive reformers and immigrants eager to assimilate. The three education models Mexican and Japanese Angelinos designed were forms of negotiation, but they also offered students and teachers the opportunity to take control of their own Americanization experience in spite of the racialized constraints they faced.

One student who learned from several of these models was John Aiso. This article began with his speech at Hollywood High School's oratory contest in 1926. It concludes by comparing that award-winning text to one of the columns Aiso sent to the Los Angeles Times during his postgraduate year in Japan. A close reading of the two statements by the city's most accomplished orator reveals several ways in which nonwhite immigrants used language learning to gain access into American civic life. Aiso's first oratorical contest came in 1923, when the sophomore "silver tongue" gave a speech titled "Lincoln's Devotion to the Constitution" that would make any Diploma Plan teacher proud. ${ }^{105}$ In 1927, the Times published one of his editorials, "As Japan Sees America," when he was studying in Tokyo under the building bridges model of international diplomacy. ${ }^{106}$ The two titles acknowledge the range of geopolitical influences on a second-generation youth coming to terms with his own abilities to participate in American civic discourse without abandoning the ethnic identity inherited from his parents. Aiso aimed these declarations at different audiences, but the settings in which he delivered them illustrate key aspects of multiple Americanization models. He spoke about Abraham Lincoln at a contest sponsored by the Federated Japanese Young Men's Association of Southern California-affiliated with the transnational language instructors who argued that teaching Nisei Japanese would make

${ }^{105}$ John Aiso, "Lincoln's Devotion to the Constitution," in Nisei Voices: Fapanese American Students of the 1930s-Then \& Now, ed. Joyce Hirohata and Paul Hirohata (Oakland, Hirobata Design, 2004), 191-193.

${ }^{106}$ Aiso, "As Japan Sees America." 
them better American citizens. Four years later, Aiso's column from Tokyo introduced the "bridges of understanding" concept to the Times' largely white readership.

These speeches show how Nisei like Aiso used many school experiences to promote world friendship. He was a talented orator who articulated the interwar ideals of both Japan and America. When he wrote the Times essay in Tokyo, Aiso stressed Japan's "admiration for and devotion to the United States." Pointing out Theodore Roosevelt's role in resolving the Russo-Japanese War of 1907, he declared that the Atlantic era of "Elizabethan accomplishments" had given way to the "dawn of a new Pacific era." Although some Anglo Americans suspected Japanese immigrants of harboring "imperial ambitions" to colonize America, Aiso believed Nisei like him could clear up such "misunderstandings" and persuade fellow citizens stateside that "the hearts of the Pan-Pacific countries are attuned to friendship." 107 As an American-born citizen of Japanese descent studying in the land of his parents' birth, the John Aiso of 1927 viewed the elusive balance of "international understanding and friendship" with the same sort of awe in which he had held Lincoln's devotion to the Constitution as a tenth grader at Hollywood High four years earlier. The essay Aiso wrote in Tokyo represented the efforts of other Nisei Angelinos who took Japan study tours, as well as Spanish-speaking students who attended Mexican Consulate schools in LA. Immigrant students and teachers transformed the language curriculum in Los Angeles into vehicles of Americanization that they hoped would provide pathways to American citizenship.

Aiso's speeches, and the Americanization agendas of Mexican and Japanese Angelinos, were attempts to reverse the school district's efforts to deny nonwhite immigrants access to citizenship. While the Home Teacher Act offered a curriculum to assimilate foreign-born mothers to American lifestyles, it did not naturalize immigrant mothers. While the Los Angeles Diploma Plan did administer naturalization exams, its classes were open only to white, English-speaking foreigners. Despite these restrictions, Aiso used Hollywood High oratory contests to show that he was a fully engaged US citizen. In his 1923 speech on Abraham Lincoln, Aiso's eloquent explanation of Lincoln's "God-like" ability to preserve the Constitution's legal and moral integrity demonstrated his "loyal devotion" to American law. But Aiso's interest in the political path of Lincoln's "paramount object" from saving the Union to abolishing slavery may have also represented his struggle to square American ideals with the racial prejudice he had experienced. After all, in 1922 he had quoted Lincoln in the speech that

${ }^{107}$ Ibid. 
temporarily elected him student body president. Ironically, the patriotism that forced his junior high school to suspend student government won first prize at the Federated Japanese Young Men's Association the next year. The same speech the school district had used to dismiss a nonwhite student from civic participation became a symbol of Nisei loyalty within LA's Japanese American community. ${ }^{108}$

Even during wartime internment, John Aiso used language education to mark his status as an American citizen. In 1941, the graduate of Brown University and Harvard Law School left his legal career to volunteer for the US Army. In November, weeks before the bombing of Pearl Harbor, a general asked Aiso to teach intelligence officers how to speak and read Japanese. During the war, Aiso became the founder and supervising instructor of the Military Intelligence Service Language School, training six thousand Nisei students to serve as translators and interrogators throughout the Pacific theater. This school remained a military secret for three decades, but it rebuked the premise of LA school district officials who had denied Aiso access to student government and national oratory contests in the 1920s. While Anglo educators devised models of immigrant education to restrict nonwhite immigrants from the rights and privileges of US citizenship, Mexican and Japanese students and teachers developed their own ideas about language instruction to show that they were vital members of American society. ${ }^{109}$

${ }^{108}$ Ibid.; Ichinokuchi and Aiso, "John Aiso and the M.I.S.," 5.

${ }^{109}$ Ichinokuchi and Aiso, "John Aiso and the M.I.S.," 13-22. 